\title{
DECENTRALIZATION OF INTER-BUDGET RELATIONS: THEORY, PRACTICE, AND INTERNATIONAL EXPERIENCE
}

\author{
Liudmyla Pidchosa', Igor Lyutyy' ${ }^{2}$, Oleksandr Pidchosa ${ }^{3}$
}

\begin{abstract}
The purpose of the article is to justify the methods of budget policy for the redistribution of cash flows in terms of differentiating powers at different levels of government and to analyse intergovernmental regulation improvement. The subject of the study is the methods of budget policy and intergovernmental regulation improvement. Research methodology. The research is based on analysis, comparison, and generalization of statistical data concerning territorial development, distribution of production capacities, migration of population and its determinants, statistical data on the state of macro-financial turbulence. The hypothesis is based on the above data. Practical implication. The budget policy is directed to reaching a certain socio-economic effect at a certain stage of social development, is implemented by the authorities with appropriate powers in a certain territory. In the administrative and budgetary reform, intergovernmental relations are multidimensional and their research needs to be conducted from the point of their categorization in terms of scale and long-term achievement of the set goals and objectives, as well as depending on priorities in the budget process management. Achievement of the effective system of intergovernmental relations is possible only if there is the unity of all subjects of the budget system. In this context, the most pressing issues of intergovernmental interactions and regulation of cash flows are highlighted. Value/originality. The proposed model of principles, tools, and mechanism of distribution and regulation of intergovernmental fiscal flows will provide an opportunity to ensure the unity of all levels of the budget system and their interaction, which, in turn, will ensure macro-financial stability of the state, efficient allocation of budget expenditure, development of society's democratization and uniform socio-economic development of some regions.
\end{abstract}

Key words: budget, intergovernmental fiscal regulation, fiscal decentralization, local authorities, territorial justice, editing coefficient, negative transfers, governmental grants, subsidies, local communities, local budgets.

JEL Classification: H61, H68, H72

\section{Introduction}

In the conditions of permanent changes, escalation of the military situation in Eastern Ukraine, national currency depreciation, population migration and other factors of macro-financial instability, one of the main tasks facing the Ukrainian economy is the construction of an innovative socio-economic mechanism enabling to balance the financial system of the country while implementing economic reforms.

Increasing efficiency of the budget system functioning and equal systematic inter-budgetary relations are especially important in the context of strengthening processes of democratization, decentralization, and the growing role of local communities. Such an approach predetermines the priority of theoretical and practical problems requiring scientific reflection, legislative and, consequently, practical solutions at various levels of implementation of the budget process in Ukraine. First of all, the range of such issues includes the provision of the revenue part of the budgets of cities and regions and the formation of effective budget interaction at different levels. These issues can be solved with purposeful Government policy; meaningful and effective financial control; budget fund audit; introduction of a system of incentives and penalties. They also need conditions of implementation of stimulating fiscal policy at regional levels and direct interaction of all subjects of financial relations and local government bodies.

\section{Analysis of recent research and publications}

According to the general theory of social welfare in economic science, the main criterion of effectiveness is the satisfaction of personal needs on the basis of

\footnotetext{
Corresponding author:

${ }^{1}$ Kyiv City State Administration, Ukraine.

E-mail: 1.pidchosa@ukr.net

${ }^{2}$ Taras Shevchenko National University of Kyiv, Ukraine.

E-mail: igorlut@gmail.com

${ }^{3}$ Institute of International Relations of Taras Shevchenko National University of Kyiv, Ukraine.

E-mail: oleksandr.p@ukr.net
} 
the Pareto optimality criterion. The essence of public goods is the commonality and equality of consumption. The effective allocation of resources is based on the rational and optimal placement of factors of production, such as scientific potential, land, labour, and capital. Thus, the efficiency of the country's economic system is an estimated category.

The theory of decentralization became the further development of the theory of public goods. This theory is based on the assertion that decentralization of power is the key to the rational allocation of resources. The treatment of this statement is interconnected with the concept of external effects and is manifested in the following interconnections: negative phenomena at the local level can lead to an appropriate response at the regional and state levels in the public and private sectors. A similar situation occurs with positive phenomena. According to this concept, territorial associations are the basic unit of the public sector and public finance economy.

Following the classics A. Pigou, P. Samuelson and R. Musgrave, the world-leading economists consider decentralization of power from the point of view of the most effective provision of public goods with a diverse range of use and the most efficient allocation of budgetary funds. As a result, this mechanism will promote efficient division of powers and jurisdiction between government levels.

Richard Musgrave states in his works that the provision of public services and goods is spatially limited. Thus, public goods can be distributed depending on the range of their provision. For example, state defence can accordingly be attributed to a large range of provisions; as well as pre-school education for children is respectively referred to a small range. Also, the higher is solvent demand from some consumers, the lower is the spending of individual consumers of public goods. As a result, the need for a spatial association of consumers with relatively similar needs can be argued. That in turn will lead to the fact that each consumer automatically becomes a member of a certain defined financial community whose main purpose is to provide him/her with certain public goods. According to the above, it is necessary to balance the cash flows of the territories, achieve equal distribution of social services and benefits throughout the country and create financial support funds. Services of adjacent local territorial associations may be duplicated; therefore, the principle of allocation requires their interaction in order to avoid double costs.

\section{Formulating the goals of the article}

The main objective of restructuring intergovernmental fiscal relations is closely connected with the general objectives of state policy. These objectives include economic growth, improving the quality and standards of living of the population, democratization of the society, increasing efficiency and accountability of the government, and achieving macro-financial stability. They should be achieved using the criteria of economic efficiency, budgetary responsibility, social justice, and political consolidation. Political consolidation in this context can be defined as the process of consolidation of unity and accord of social and political forces (people, social groups, political parties and public organizations, etc.) in order to strengthen their responsibility and determination to solve common problems.

Thus, the operational goal of fiscal decentralization reform is real decentralization of the budget system, namely, the expansion of official powers and responsibilities (budget autonomy) of territorial associations, while creating and strictly adhering to unified rules in relations between different branches of government.

According to foreign experience, all models of fiscal decentralization are formed to achieve territorial (regional) justice. At the same time, it is necessary to focus on the most successful approaches in the foreign practice of fiscal policy regarding equalization of territorial development of regions, elimination of vertical and horizontal imbalances in the socioeconomic development of the state.

\section{Statement of the base line}

Inter-budgetary relations in the context of fiscal decentralization act as both economic and political concepts. From the political point of view, it is possible to consider this term from the standpoint of state law where intergovernmental relations act as a form of government based on the principle of subsidiarity and the idea of basic democracy. Regarding the economic aspect, in the context of fiscal decentralization, intergovernmental fiscal relations represent a system of decentralized use of public funds formed according to the principle of effective allocation of resources. The above two directions are closely interconnected and cooperate with each other. Namely, the first direction within defines the purpose and objectives of the principle of subsidiarity. The second direction resolves the task and purpose within the framework of the theory of fiscal decentralization defining the criteria for decentralization and ways of implementing this idea in practice.

The effective allocation of resources is based on the rational and optimal placement of production factors, such as scientific potential, land, labour, and capital. Thus, the efficiency of the country's economic system is an estimating category.

One of the main aspects of the regulation of intergovernmental fiscal cash flows is the interaction of all levels of government with financial responsibility in accordance with their powers in order to maximize the effectiveness of the provision of public services of 
a varying range of action. The term fiscal decentralization is defined by the above-mentioned in the expert environment.

As for functioning of the state, the principle of effective allocation of resources at all levels of decentralization of power determines its targeting solely on the interests and needs of citizens and implementation of functions using the minimum amount of resources.

\section{Datasets and methods}

\subsection{Study area}

The current challenges faced by the Ukrainian economy are caused by many destabilization factors which, in turn, lead to macro-financial instability (Table 1) and intergovernmental imbalances (Table 2). Because of the unfavourable economic climate in Ukraine, aggravation of migratory mindset and increase of labour migration, the World Bank forecasts that Ukraine as a state may face a shortage of skilled labour and ablebodied young people in the near future, and hence the lack of a rising and promising young generation.

Along with the situation of macro-financial instability, since April 2014, the Government of Ukraine has begun reforming local self-government and territorial organization of power. Thus, in the period from
2015 to 2018 , there are 728 amalgamated territorial communities (ATCs).

These amalgamated territorial communities (ATC) are composed of 3378 former local councils (State Statistics Service of Ukraine, 2017) where 6.3 million people live. Adjustments were made to the Budget Code of Ukraine during this period. However, there is still no clear budget strategy in this direction, no clear legislative constraints or mechanism of budget decentralization itself. An effective public financial control has not been introduced either, especially in the context of the democratization of society.

Consequently, a model of intergovernmental regulation of money flows needs to be developed; it will be an element of an innovative socio-economic mechanism to balance the financial system of the country.

\subsection{Data Sources}

The datasets used in this study include: (1) Ukraine's GDP for 2008-2018 taking into account data updates; (2) macro-financial indicators of Ukraine for 2008-2018 taking into account data updates; (3) indicators of the amalgamated territorial communities (ATC) (including data on ATC formation, ATC macrofinancial indices, ATC population dynamics).

Table 1

Implementation of local budgets by income (taking into account transfers from the state budget), US dollars

\begin{tabular}{|l|c|c|c|c|c|c|}
\hline \multicolumn{1}{|c|}{ Region } & 01.12 .2017 & 01.12 .2016 & 01.12 .2015 & 01.02 .2014 & 01.12 .2013 & 01.12 .2012 \\
\hline Vinnytsia & 656764770 & 469871947 & 440773154 & 23402307 & 312295690 & 289627476 \\
\hline Volyn & 445254282 & 321786796 & 310035241 & 8617324,1 & 162899446 & 156531787 \\
\hline Dnipropetrovsk & 1448054291 & 1106206762 & 1048154725 & 59993335,8 & 1156471263 & 1109381413 \\
\hline Donetsk & 782976263 & 602306882 & 656250849 & 68498738,6 & 1414854555 & 1311542661 \\
\hline Zhytomyr & 515168842 & 380864370 & 350340936 & 12782229,2 & 245306785 & 232628073 \\
\hline Zakarpattia & 457940498 & 338242333 & 336189080 & 8515308 & 164959144 & 154574109 \\
\hline Zaporizhzhia & 739145656 & 570141442 & 509334292 & 25497209,1 & 506090626 & 486496207 \\
\hline Ivano-Frankivsk & 556307893 & 422514173 & 383572115 & 10416014,4 & 217846540 & 218559322 \\
\hline Kyiv & 850067845 & 595469294 & 525472230 & 26303390 & 529988526 & 480618712 \\
\hline Kropyvnytskyi & 399791690 & 297873330 & 276892661 & 10517480,8 & 212492608 & 199698087 \\
\hline Luhansk & 263568102 & 208214987 & 233400724 & 27726593,8 & 507556768 & 520547098 \\
\hline Lviv & 1051427187 & 771439204 & 711668606 & 24406829,3 & 502459048 & 484711066 \\
\hline Mykolaiv & 441222944 & 333821403 & 320148684 & 13371562,4 & 257216016 & 258906613 \\
\hline Odesa & 949424185 & 704767921 & 659572749 & 32772989,8 & 583681867 & 555798805 \\
\hline Poltava & 667416629 & 496066447 & 436451820 & 22277997,7 & 438611881 & 448962424 \\
\hline Rivne & 483355695 & 347117901 & 338383232 & 9932386,04 & 201816271 & 195872684 \\
\hline Sumy & 459526385 & 354164312 & 304439755 & 14937934,7 & 248055262 & 244841347 \\
\hline Ternopil & 414396585 & 319084485 & 282123425 & 7252232,2 & 153495656 & 141268739 \\
\hline Kharkiv & 1029029873 & 796942832 & 717287316 & 37046646,1 & 725954254 & 697641652 \\
\hline Kherson & 382667181 & 287744586 & 280425538 & 14447165,1 & 191536707 & 185533579 \\
\hline Khmelnytskyi & 529913969 & 389709862 & 358449522 & 13777670,1 & 248652527 & 227093627 \\
\hline Cherkasy & 528651322 & 390592319 & 349510879 & 14270087,1 & 281665024 & 279184954 \\
\hline Chernivtsi & 331988233 & 255464466 & 238962298 & 7648303,49 & 144586694 & 131566707 \\
\hline Chernihiv & 427464282 & 310409550 & 278467245 & 11721172,1 & 203175444 & 196724142 \\
\hline The City of Kyiv & 1620098536 & 1326963573 & 1273701471 & 76555146,4 & 1448779257 & 1399894550 \\
\hline Soure: & & & & \\
\hline
\end{tabular}

Source: The table is compiled by the authors based on the State Statistics Service of Ukraine data 
Vol. 5, No. 4, 2019

Baltic Journal of Economic Studies

Table 2

Statement of equalization from the state budget to regional budgets of Ukraine, thousand US dollars

\begin{tabular}{|c|c|c|c|c|c|c|}
\hline Regional budget & 2012 & 2013 & 2014 & 2015 & 2016 & 2017 \\
\hline Vinnytsia region & 131014 & 140568 & 103980 & 3310 & 1773 & 1536 \\
\hline Volyn region & 63137 & 82657 & 62155 & 3462 & 2671 & 2229 \\
\hline Dnipropetrovsk region & 24079 & 36793 & 18908 & 0 & 0 & 0 \\
\hline Donetsk region & 100429 & 101353 & 122897 & 0 & 0 & 0 \\
\hline Zhytomyr region & 70783 & 98467 & 62338 & 2649 & 1538 & 1530 \\
\hline Zakarpattia region & 63822 & 82380 & 58387 & 5263 & 3827 & 3931 \\
\hline Zaporizhzhia region & 71064 & 92175 & 69328 & 0 & 0 & 0 \\
\hline Ivano-Frankivsk region & 58909 & 84888 & 64044 & 4131 & 3885 & 4278 \\
\hline Kyiv region & 33986 & 46929 & 37619 & 0 & 0 & 0 \\
\hline Kropyvnytskyi region & 52168 & 64096 & 43628 & 1584 & 921 & 1013 \\
\hline Luhansk region & 94701 & 115671 & 91482 & 1128 & 582 & 798 \\
\hline Lviv region & 105203 & 151920 & 113088 & 2041 & 610 & 1075 \\
\hline Mykolaiv region & 65008 & 81015 & 58499 & 1505 & 1339 & 955 \\
\hline Odesa region & 81109 & 115148 & 81143 & 465 & 500 & 0 \\
\hline Poltava region & 26954 & 65081 & 42235 & 0 & 0 & 0 \\
\hline Rivne region & 59412 & 79173 & 56561 & 3292 & 2250 & 2495 \\
\hline Sumy region & 47817 & 76858 & 51976 & 385 & 501 & 594 \\
\hline Ternopil region & 59991 & 77370 & 55325 & 3127 & 2081 & 3364 \\
\hline Kharkiv region & 61971 & 115682 & 85039 & 0 & 0 & 0 \\
\hline Kherson region & 65318 & 81306 & 57187 & 3499 & 2356 & 2620 \\
\hline Khmelnytskyi region & 75583 & 93179 & 66366 & 3448 & 1732 & 1954 \\
\hline Cherkasy region & 57422 & 74989 & 53707 & 1654 & 1005 & 811 \\
\hline Chernivtsi region & 47139 & 60957 & 44395 & 3987 & 2998 & 3587 \\
\hline Chernihiv region & 49684 & 70038 & 48637 & 2097 & 1225 & 903 \\
\hline The City of Kyiv & 0 & 15594 & 0 & 0 & 0 & 0 \\
\hline
\end{tabular}

Source: The table is compiled by the authors based on the State Statistics Service of Ukraine data

\subsection{Methods}

The study of inter-budgetary regulation of cash flows as a condition for self-realization of local budgets was carried out in classic fashion: (1) the choice of subject, object; definition of the purpose and objectives of the study; (2) accumulation of information; (3) development of hypotheses; (4) choice of research methods; (5) processing and analysing of the results of experimental research; (6) writing the text and presentation of results.

In this study, we aim to explore the main aspects of the model of intergovernmental fiscal regulation connected with the European integration processes in Ukraine, the need to restructure the budget system, development of the society democratization, and the need to achieve macro-financial stability. In this research, we identify the leading aspects of international experience in this area, including achievement of budgetary equilibrium, the formation of territorial development funds, and analysis of necessary changes at the legislative and executive levels.

To analyse the current ATC state and the possibility of achieving budget security in line with the financial security of the territories, the method of analysis was used, namely: the specific international experience of fiscal decentralization and budgetary decentralization in the context of restructuring the budget system were analysed. The formalization method: used to construct hypothetical-deductive models of functioning of budget decentralization elements; constructing a model of linear dependence for determining indicators of influence on the macroeconomic situation in the country. The hypothetical method was used in the process of developing the hypothesis. The observation was used throughout the whole research period to monitor changes in the global economy, in the national economy that could have affected the process of budget decentralization or shape its specific characteristics. The comparison was used in the research process of the role of fiscal decentralization and its impact on the achievement of macro-financial stability; budget decentralization in the countries of the world as a factor of democratization of the society; reconfiguration of strategies and mechanisms of interaction of fiscal decentralization of world budget systems and their elements.

To study the issue of fiscal decentralization and the issue of achieving budget balance, we divided the whole Ukraine into the following categories: strong, medium, and weak territories, depending on industrial production (Figure 1) and the regional gross product (Figure 2). The time period from 2008 to 2018 was investigated (Table 3). 


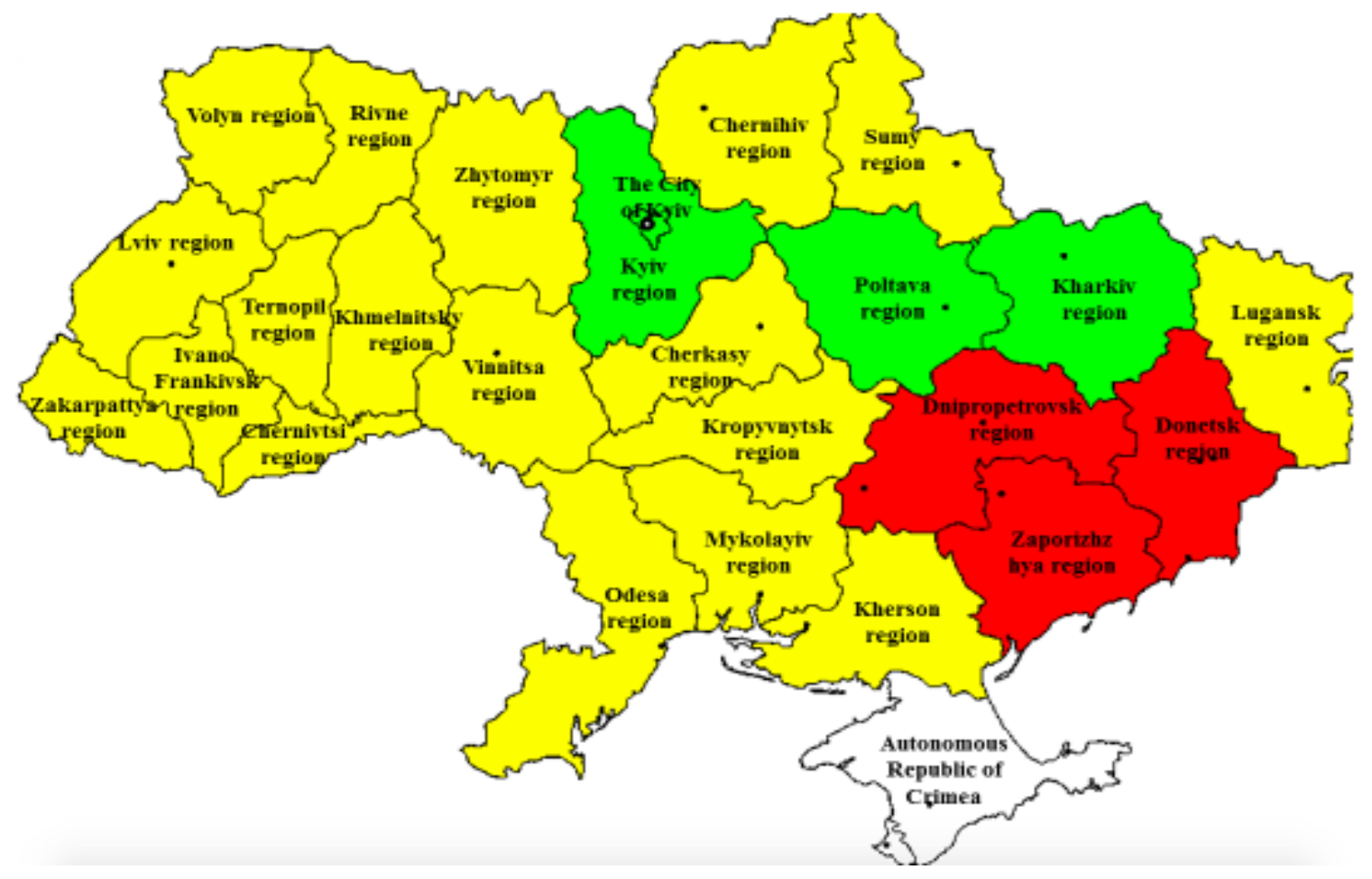

Figure 1. Classification of regions of Ukraine according to the volume of sold industrial products (goods and services)

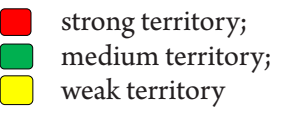

Table 3

Regional gross product, $\$$

\begin{tabular}{|l|c|c|c|c|c|c|c|c|c|}
\hline \multicolumn{1}{|c|}{ Regions } & 2008 & 2009 & 2010 & 2011 & 2012 & 2013 & 2014 & 2015 & 2016 \\
\hline Ukraine & 189611 & 114168 & 135321 & 162760 & 182387 & 190332 & 132243 & 90388 & 91745 \\
\hline Vinnytsia & 4019 & 2513 & 2949 & 3637 & 4128 & 4524 & 3666 & 2721 & 2862 \\
\hline Volyn region & 2557 & 1528 & 1804 & 2205 & 2501 & 2578 & 2016 & 1440 & 1375 \\
\hline Dnipropetrovsk & 20937 & 11666 & 14517 & 17503 & 18496 & 19113 & 14712 & 9782 & 9403 \\
\hline Donetsk & 23529 & 12967 & 16123 & 20128 & 21347 & 20616 & 9999 & 5228 & 5288 \\
\hline Zhytomyr & 3002 & 1841 & 2343 & 2741 & 3106 & 3210 & 2485 & 1747 & 1843 \\
\hline Zakarpattia & 2642 & 1568 & 1912 & 2257 & 2676 & 2675 & 2010 & 1316 & 1246 \\
\hline Zaporizhzhia & 8489 & 4681 & 5342 & 6191 & 6854 & 6794 & 5497 & 4048 & 4012 \\
\hline Ivano-Frankivsk & 3577 & 2155 & 2556 & 3344 & 4036 & 4150 & 3137 & 2084 & 1977 \\
\hline Kyiv & 7137 & 4694 & 5619 & 7394 & 8708 & 8616 & 6630 & 4729 & 4948 \\
\hline Kropyvnytskyi & 2792 & 1674 & 1969 & 2505 & 2757 & 3164 & 2397 & 1748 & 1770 \\
\hline Luhansk & 8597 & 4806 & 5693 & 7150 & 7346 & 6889 & 2616 & 1084 & 1206 \\
\hline Lviv & 7107 & 4494 & 5207 & 6513 & 7745 & 7916 & 6077 & 4304 & 4417 \\
\hline Mykolaiv & 3882 & 2542 & 3007 & 3454 & 3651 & 4004 & 2951 & 2191 & 2224 \\
\hline Odesa & 9399 & 6081 & 6735 & 7687 & 8093 & 8720 & 6245 & 4535 & 4608 \\
\hline Poltava & 6824 & 4204 & 5536 & 6532 & 7073 & 7308 & 5819 & 4358 & 4472 \\
\hline Rivne & 2815 & 1684 & 1985 & 2413 & 2724 & 2751 & 2394 & 1602 & 1518 \\
\hline Sumy & 3242 & 2008 & 2292 & 2863 & 3117 & 3346 & 2533 & 1889 & 1780 \\
\hline Ternopil & 2124 & 1397 & 1591 & 2037 & 2245 & 2261 & 1806 & 1212 & 1195 \\
\hline Kharkiv & 11878 & 7365 & 8162 & 9608 & 10278 & 10664 & 8050 & 5675 & 5957 \\
\hline Kherson & 2635 & 1680 & 1956 & 2306 & 2420 & 2596 & 1938 & 1464 & 1490 \\
\hline Khmelnytskyi & 3212 & 1970 & 2262 & 2855 & 3280 & 3303 & 2680 & 1868 & 1879 \\
\hline Cherkasy & 3820 & 2338 & 2794 & 3377 & 3908 & 4136 & 3206 & 2311 & 2285 \\
\hline Chernivtsi & 1767 & 1061 & 1237 & 1496 & 1646 & 1720 & 1254 & 841 & 817 \\
\hline Chernihiv & 2984 & 1830 & 2126 & 2646 & 2992 & 3030 & 2346 & 1680 & 1668 \\
\hline The City of Kyiv & 33913 & 21192 & 24580 & 27972 & 34461 & 39069 & 29781 & 20532 & 21505 \\
\hline Sourc: The table is & & & & & & & \\
\hline
\end{tabular}

Source: The table is compiled by the authors based on the State Statistics Service of Ukraine data 


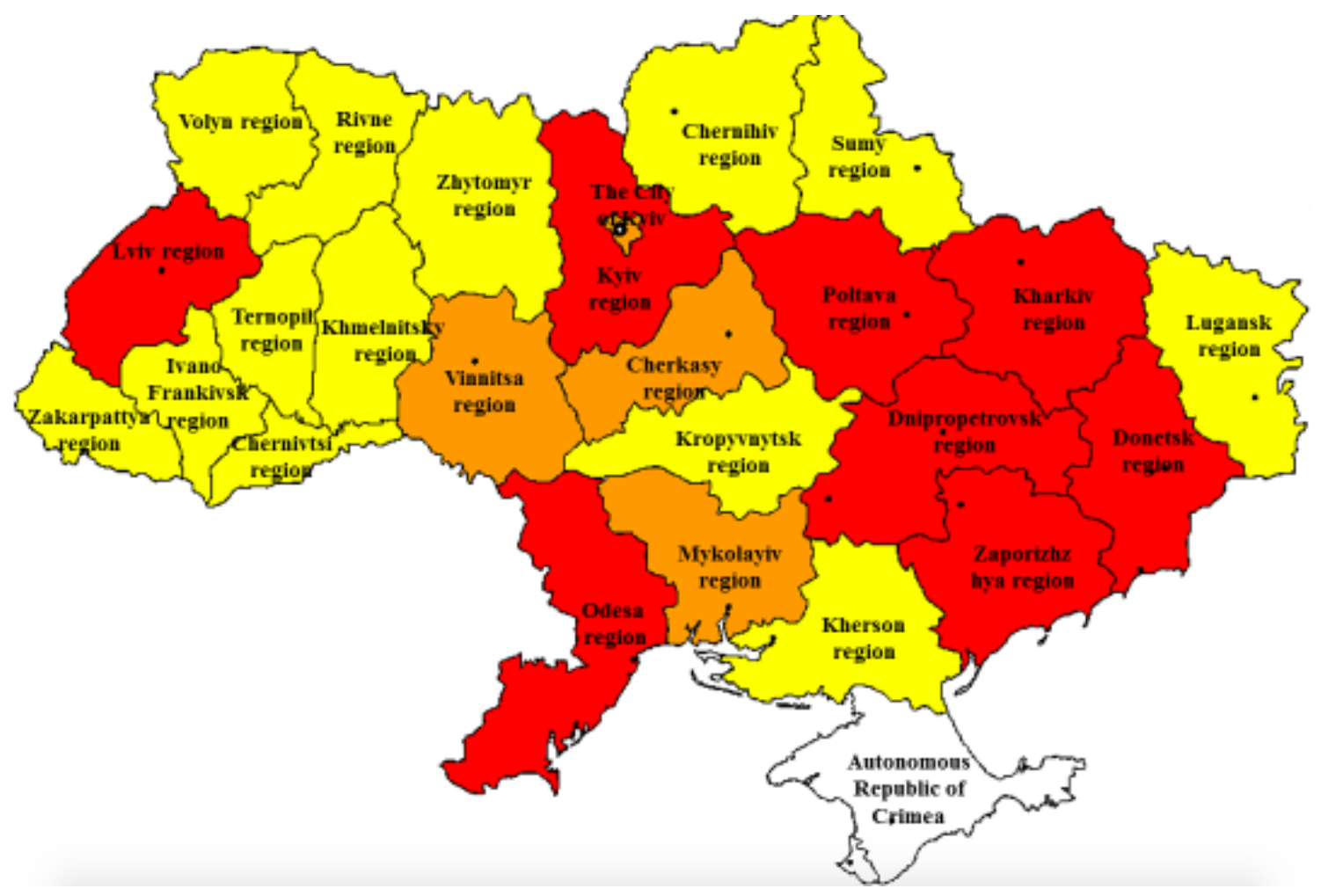

Figure 2. Classification of regions of Ukraine, according to the regional gross product

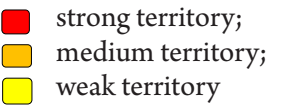

\section{Discussion of the raised problem}

The purpose of intergovernmental regulation at the regional level is to ensure local budgets with necessary financial resources, thus, allowing the implementation of certain powers secured in legislation (Figure 3; Figure 4). In this context, the main instruments of intergovernmental regulation can be:

1. Alegislative determination of the rates of deductions to local budgets from taxes subject to enrolment to the higher-level budget (National Budget of Ukraine or local (territorial) budget).

2. Grants to local budgets in order to equalize their budget security through the creation of financial support and other financial assistance.

3. Deductions from local budgets to higher-level budgets: 'negative (deductible) transfers' from budgets that are most secure (Saburov et al., 2001).
As a result, this mechanism can be allowed to provide local budgets with the necessary revenues.

The advantages and disadvantages of the aforementioned models are specified in Table 4.

Consequently, the authorities are facing the number of questions of proportional distribution of main funds of intergovernmental regulation between the transfer channels for local budget funds (Figure 5).

According to world practice, the proportion in the distribution of the major amounts of funds is chosen once for a long term (Gershberg and Winkler, 2004). The advantages of long-term deductible rates include: the ability of local authorities to independently forecast their own revenue for a long period; increased incentives in cities and regions to increase tax collection and, accordingly, increase the tax base in the territories (Figure 6).

Table 4

Advantages and disadvantages of budget decentralization models

\begin{tabular}{|l|c|c|}
\hline & German Model & American Model \\
\hline Probability of existence with significant interregional disproportions & + & - \\
\hline Possibilities for solving social policy tasks & $>$ & $<$ \\
\hline $\begin{array}{l}\text { Preservation of incentives to improve the quality of socio-economic policies } \\
\text { from representatives of regional authorities }\end{array}$ & - & + \\
\hline The degree of approaching the traditions of the Ukrainian economy & $<$ & $>$ \\
\hline
\end{tabular}

Source: The table is created by the authors 
Benefits of Decentralized Production of Public Goods

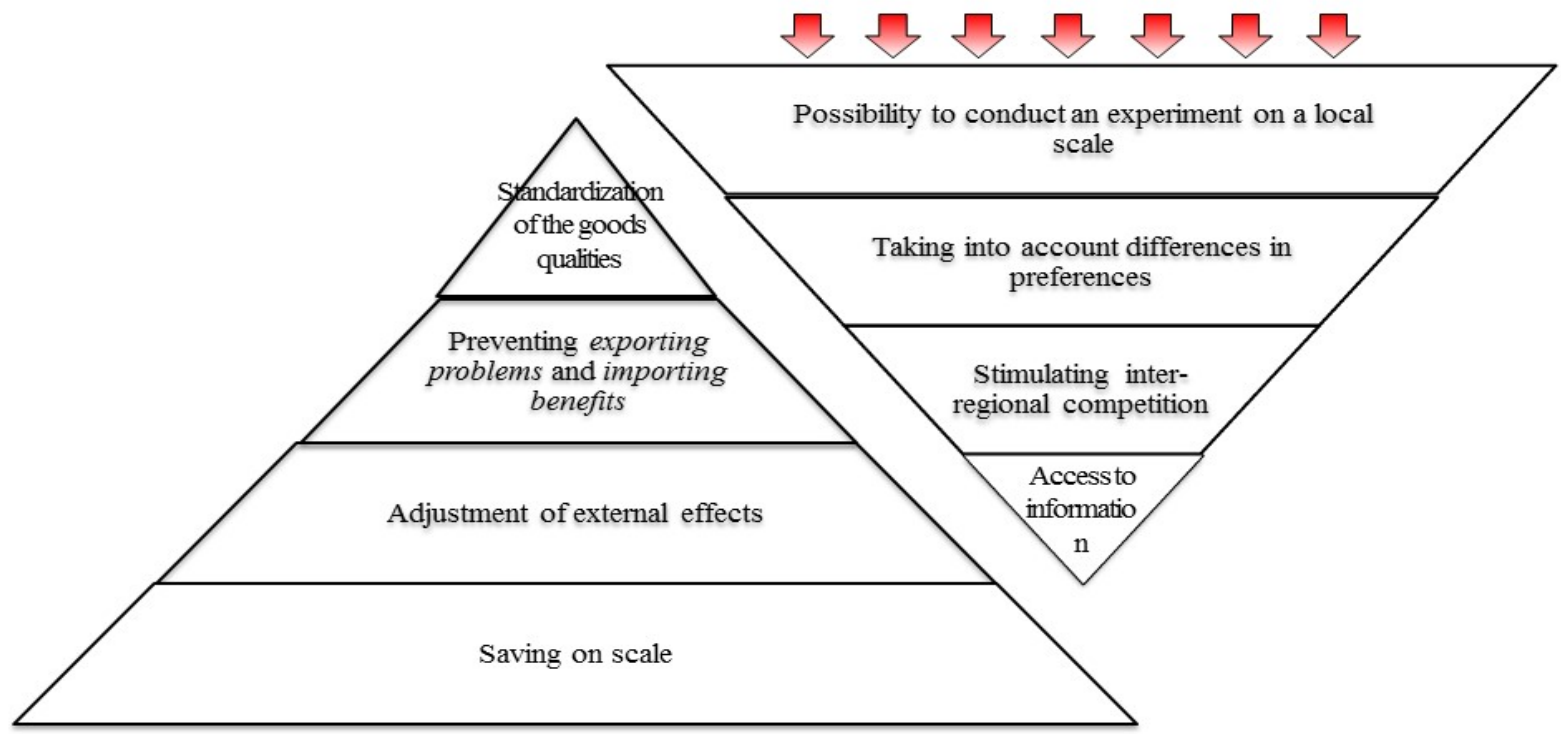

The Benefits of Centralized Production of Public Goods

Figure 3. Classical theory of fiscal decentralization

Source: The scheme is compiled by the authors based on (Saburov et al., 2001)

\section{The German Model of Cooperative Federalism}

(provisions of the Basic Law - ensuring equal conditions of life in the general territory of the country, minimum powers for territories under significant federal regulation of territorial development)

\section{The American Model of Decentralized Federalism}

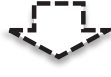

(maximum authority of the territories with insignificant federal regulation of territorial development)

Figure 4. Variety of models of fiscal decentralization

Source: Compiled by the authors based on (Saburov et al., 2001; Kyrylenko, 2002)

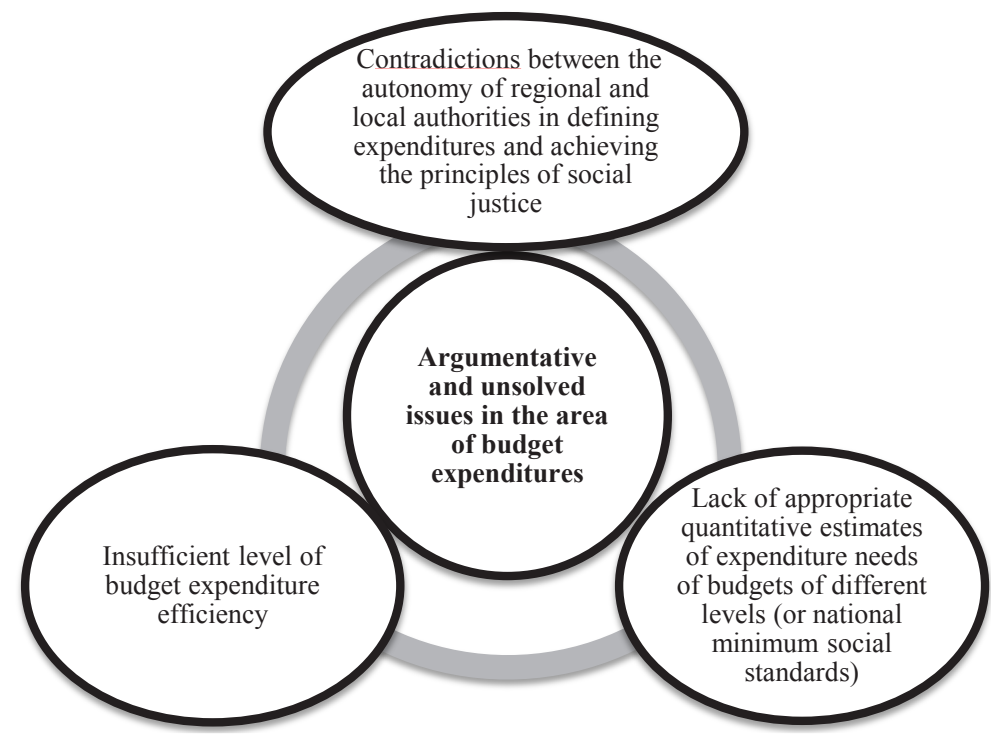

Figure 5. Disputed and unsolved issues in the field of budget expenditure

Source: The scheme is compiled by the authors 


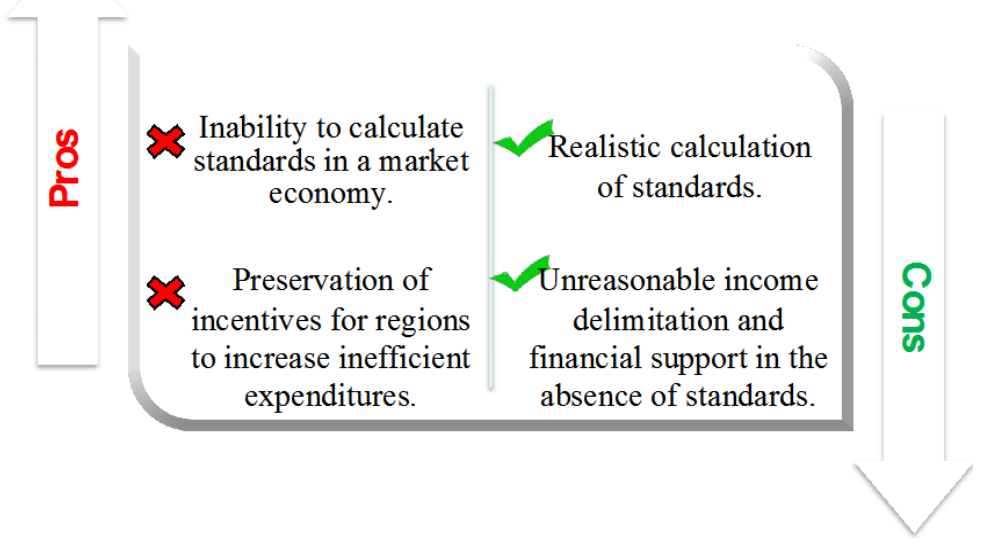

Figure 6. Quantitative standards for decentralized budget services

Source: The scheme is developed by the authors

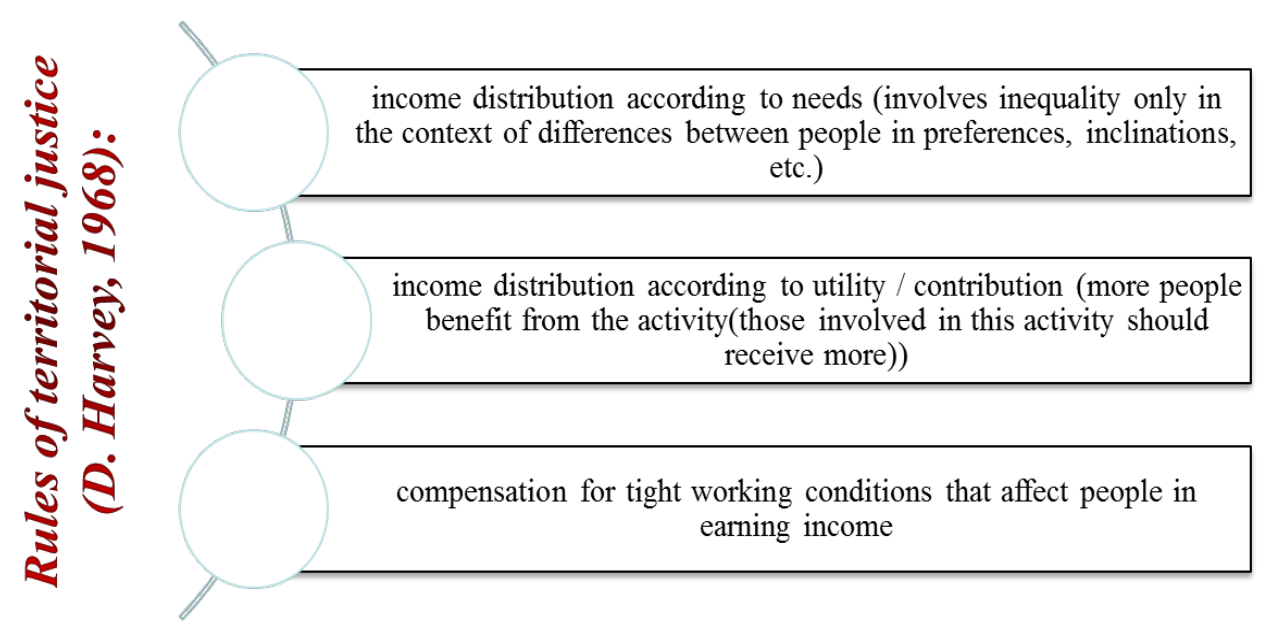

Figure 7. The concept of territorial justice

Source: The scheme was adapted and modified by the authors from (Harvey, 2010)

However, this mechanism is limited, namely, the tax base is distributed unevenly throughout the territory of Ukraine, which, in turn, can lead to a significant difference in the budget security of different territories as a result of consolidated uniform standards.

The use of inappropriate financial support for cities and regions with their own revenues makes it possible to ensure a more even fund distribution between local budgets, but this may reduce the interest of local authorities in increasing the volume of revenues and taxes and developing their own tax base (Table 5).

Providing financial support to the regions and territories of Ukraine in the form of government grants, in turn, allows public authorities to significantly influence the policy of local governments in accordance with the priorities defined at the regional level (Figure 7).

Table 5

The purpose and basic principles of providing financial assistance to lower-level budget

\begin{tabular}{|l|l|l|}
\hline \multirow{2}{*}{\begin{tabular}{l} 
Maintaining incentives for a lower-level budget to pursue an effective fiscal policy \\
\cline { 2 - 4 }
\end{tabular}} & Vertical imbalance & $\begin{array}{l}\text { Basconsistency of budget revenues of different hierarchical levels } \\
\text { and expenditures for the fulfillment of functions assigned to } \\
\text { them; }\end{array}$ \\
\cline { 2 - 4 } & Horizontal imbalance & $\begin{array}{l}\text { difference between administrative-territorial units of one } \\
\text { hierarchical level in the ability to cover expenditures by their } \\
\text { ownincome. }\end{array}$ \\
\hline
\end{tabular}

Source: The table was compiled by the authors based on (Saburov et al., 2001; Bordignon, 2006) 


\section{Options for approaches to equalizing interregional disparities:}

1. Ensuring equal living conditions throughout the country

2. Ensuring minimum social standards

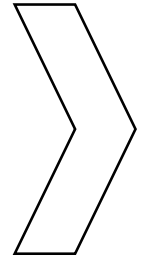

The situation in Ukraine:

The Ukrainian legislation does not regulate the obligations of the authorities regarding the equalization of interregional disproportions

There is a traditional contradiction between donor and recipient regions

Figure 8. Determining the extent of equalization of interregional disproportions

Source: The scheme was developed by the authors

Thus, the choice of proportion between the amount of funds provided to local budgets in the form of deductions from taxes, government grants, and subsidies should be determined by the ratio of priorities: stimulation of local authorities to tax base development and uniformity in financial resource distribution (Figure 8).

Similar choices should also be made by regional governments with respect to their territorial communities since the regions should also have the right to use the indicated tools (Harvey, 2010). However, it should be borne in mind that, according to world practice, territorial communities may also receive financial assistance from the regional budget, in addition to financial assistance from the regional budgets, and its amount is determined annually, whereas the norms of deductions to the budgets of territorial communities should be established by the decision of the regional representative body and should have a certain validity period (Table 6). Therefore, the options facing local governments in the year of adoption of uniform tax deductions from the budgets of territorial communities may somewhat change in subsequent years. Therefore, regional authorities can review the norms of deductions to the budgets of territorial communities with greater probability.

With regard to negative (deductible) transfers, this tool allows for an increase in the following ratio: uniform deduction rates $=>$ financial assistance. With the help of negative transfers, it is possible to set higher rates of deductions to less secured local budgets (which, in turn, will significantly increase budget security in the respective cities and regions) (Figure 9). At the same time, the rationale for using higher standards is fully preserved in the cities and regions that do not list negative transfers and match the criterion for collecting a negative transfer, since only a certain proportion (no more than 50\%) will be withdrawn from the amount of the excess of their twice-average income level (De Mello, 2000).

The financial resources that can be allocated to carry out delegated powers do not relate to their own revenues and do not affect the balance of local budgets. These funds should be allocated for financial support to implement the powers at the level of government transferring these funds. These funds' allocation should be clearly determined by the relevant budget services available in the regions and cities and, if necessary, the cost factors that reduce or increase the cost of these services.

Today, the current legislation of Ukraine needs change, namely, to establish the possibility of establishing territorial development funds to transfer government grants to local budgets for partial financing of investment programs (projects) for the development of territorially important public infrastructure, as well as regional funds for co-financing social expenditures for transferring funds to support financing first-priority socially significant expenditure of local budgets (Gershberg and Winkler, 2004). A similar scheme should be formed for regions. Changes to the Budget Code of Ukraine should allow the use of other forms of financial support for cities and regions, including budget loans (Table 7).

Direct distribution of funds through any of the funds must be carried out according to a unified method and/or based on the common criteria and conditions for all types of cities and regions that must be established by Ukrainian Legislature.

Table 6

Forms of intergovernmental transfers at the regional level

\begin{tabular}{|c|c|}
\hline \multirow{4}{*}{ 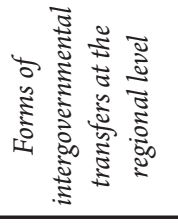 } & Funds provided to local budgets to equalize their budget security through financial support funds \\
\hline & Grants from regional funds for financial support of territorial communities \\
\hline & Grants from regional funds for financial support of districts \\
\hline & Grants from district funds for financial support of territorial communities \\
\hline
\end{tabular}

Source: The table was compiled by the authors based on (De Mello, 2000) 


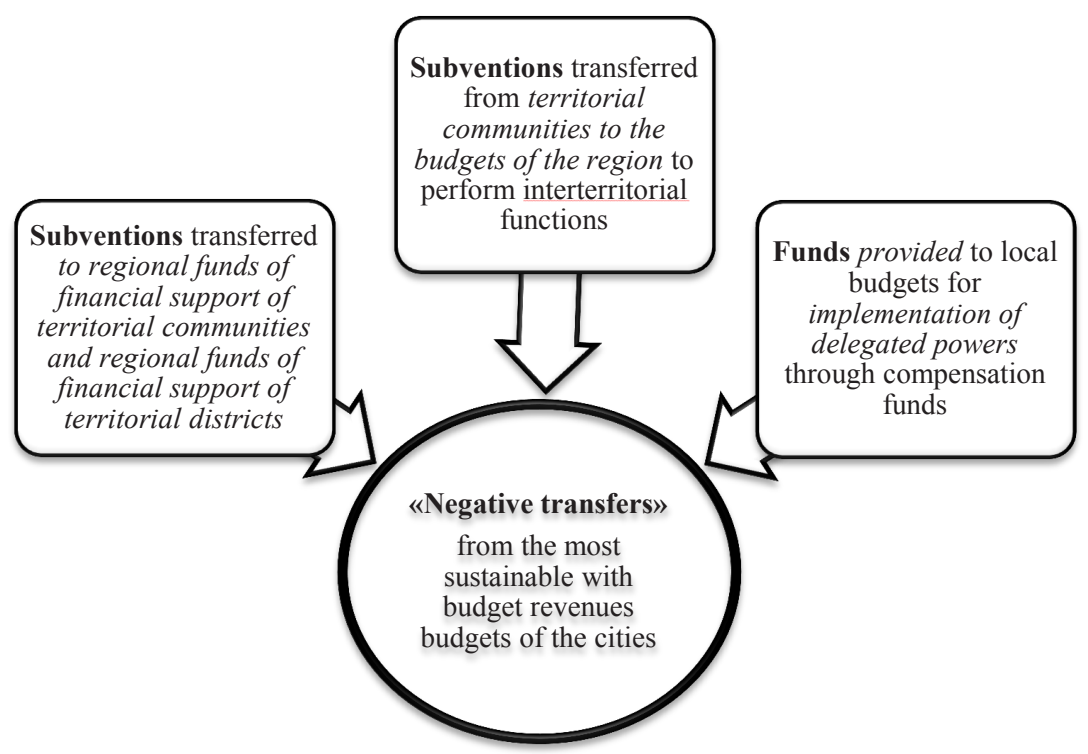

Figure 9. Negative transfers from the most sustainable city budgets

Source: The scheme was created by the authors based on (Gershberg and Winkler, 2004)

Table 7

Budget loans for regions (source of deficit financing) ${ }^{1}$

\begin{tabular}{|l|}
\hline The purpose of providing budget loans: \\
\hline 1. to partially cover the budget deficit of districts, regions, cities of Ukraine (for up to three-year term); \\
\hline 2. to cover temporary cash disruptions (for up to three-year term); \\
\hline 3. to implement measures to eliminate the consequences of natural and industrial disasters (for a term up to three years at a $0 \%$ rate); \\
\hline 4. for construction; reconstruction; overhaul; repair and maintenance of public roads (for a term up to five years); \\
\hline 5. for implementation of measures to support the monocities of Ukraine in total (for a term up to 3 years); \\
\hline The loan fee is $1 / 4$ of the refinancing rate of the National Bank of Ukraine \\
\hline
\end{tabular}

Source: The table was developed by the authors based on (Patsias et al., 2013)

Regional funds of financial support for territorial communities and local budgets are necessary for the provision of undesignated financial assistance (grants), their use should be within the competence of the recipient but comply with the current legislation. This fund distribution mechanism is aimed at providing financial resources to relevant local budgets for solving issues within the competence of local governments of the respective levels of the budget system (De Mello, 2000).
The issue of government grants also needs further elaboration, namely, in consolidating the possibility of delegating to the subjects of the highest level the authority to provide subsidies to territorial communities at the expense of the regional budget (Table 8 ). The funds for implementation of this delegated authority should be provided to higherlevel entities from the Regional Compensation Funds (Prud'Homme, 1995). This mechanism should be clearly defined in the legislation of Ukraine.

Table 8

Comparison of subsidies to equalize budget coverage to support measures ensuring the balance of regional budgets

\begin{tabular}{|c|c|c|}
\hline & Grants for equalization & Grants for providing balance \\
\hline Approval of the Law on the State Budget & $\begin{array}{l}\text { Volumes in general and for each recipient } \\
\text { region are approved; }\end{array}$ & $\begin{array}{l}\text { The total volume is approved; it is distributed by } \\
\text { regions by the Government during the year; }\end{array}$ \\
\hline $\begin{array}{l}\text { The degree of "transparency" of distribution } \\
\text { methods by region }\end{array}$ & Significant (advantage) & Low (drawback) \\
\hline $\begin{array}{c}\text { Possibility of prompt response to the situation in } \\
\text { the regions }\end{array}$ & Missing (drawback) & Available (advantage) \\
\hline
\end{tabular}

Source: The table was compiled by the authors based on (De Mello, 2000)

\footnotetext{
${ }^{1}$ Monocity is a locality that depends on one or several city-forming enterprises in terms of employment and infrastructure. The word monocity is a reduction of the monoprofile city concept where the prefix 'mono' means 'sole'.
} 


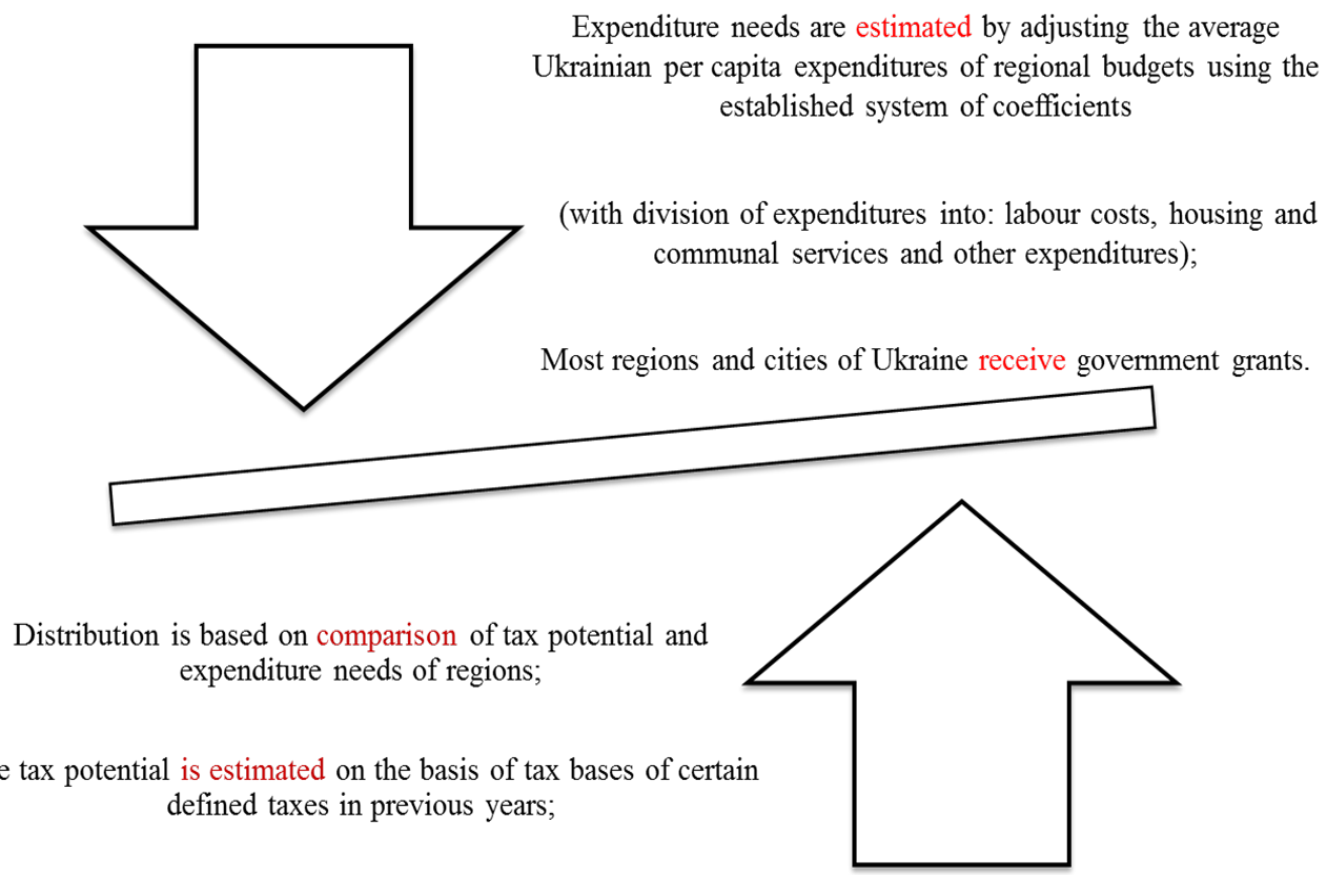

Figure 10. Distribution of subventions by regional fund of financial support

Source: The table was created by the authors based on (De Mello, 2000)

As a result, this mechanism will prevent the emergence of imbalances in the alignment of the budgetary provision of territorial communities, which may arise when levelling their budgets directly at the regional level.

A new type of intergovernmental transfers (subventions) - negative transfers - should be levied from the most secured cities and regions to reallocate these funds to other, poorly resourced cities and regions (Figure 10). Negative transfers paid from local budgets should be credited to the Regional Fund of Financial Support of separate territorial communities (Prud'Homme, 1995). According to the current legislation and approved by the Verkhovna Rada of Ukraine, negative transfers paid from district budgets should be credited to the Regional Fund of Financial Support.

Transfer of such subvention from local budgets to the national budget can be provided if the estimated tax revenues of local budgets of the corresponding type are twice as high and exceed the per-city average (of the same type) per person. At the same time, the withdrawal in the form of a negative transfer is subject to no more than $50 \%$ of the amount exceeding the double level of the calculated tax revenues of the average regional level (Prud'Homme, 1995).

The procedure for calculating a negative transfer must be determined by the legislation of Ukraine.

It should be noted that in highly subsidized regions, despite the fact that the range of fiscal provision with tax revenue of cities may be substantial, it is likely that none of them is able to cover their spending needs at the expense of local and fixed taxes and fees.

When using a negative transfer, it is also necessary to take into account that after a reduction of the incomes of withdrawn cities, their budget security should be ensured to be not lower than in other cities after the disbursement of financial assistance.

Donations from the Fund of Financial Support should be directed to cities that do not list negative transfers from their budgets (Prud'Homme, 1995) (Figure 11).

In the event that the city fails to fulfil the obligation to transfer the said subvention, public authorities should have the right to reduce the rates of deductions from the national and (or) regional taxes for this city, as well as to centralize part of the proceeds from local taxes into the budget.

Funds of financial support of cities are created in order to provide them with financial resources to perform functions of local government. This task can be solved by reducing the gap between levels of cities' budget provision and sufficient levels to discharge their powers. Calculation of budget support for potential recipients ${ }^{2}$ of financial assistance and equalization procedure will be different for different funds (Prud'Homme, 1995).

The budget security of cities is the object of budget equalization. The budget security (tax revenue) is defined as the ratio of estimated tax revenues per inhabitant that can be obtained based on the level of development of the city and its economic structure (tax potential), and a similar average indicator in cities of the same type

\footnotetext{
${ }^{2}$ Recipient (lat. Recipere - receive, receive) - an object or entity that receives anything from another person or entity called donor.
} 


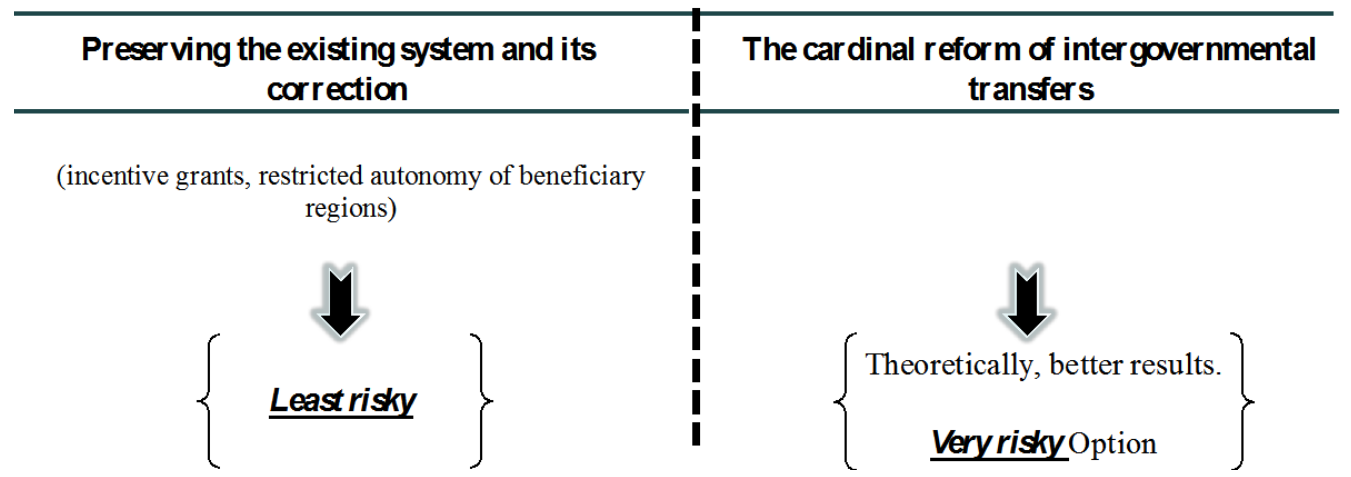

Figure 11. Options for decentralization reform of intergovernmental transfers

Source: The scheme was developed by the authors

taking into account the structure of population, social, economic, geographical, climatic and other objective factors and conditions influencing the cost of providing the same amount of budget services per capita.

Estimated tax revenues - tax potential - are estimates of revenues that can be charged to the city budget from tax sources fixed by the city budget. When calculating this value, it is not necessary to use indicators that objectively characterize the possibility of receiving tax revenues from the tax base fixed to the city but the actual income for the reporting period. This requirement has an exception during the transition period, when the assets of individual financial support funds may be partly distributed using actual and projected incomes of individual cities (Dabla-Norris and Wade, 2002).

The use of data on actual incomes in calculating budget security can lead to reduced incentives for cities to mobilize revenues, as a reduction in revenue from tax sources will be compensated (when they are included in the estimated tax revenues) by increased financial assistance in the following year. Conversely, an increase in actually received tax revenues from the local budget may lead to an adequate reduction in the amount of financial support, that is, ultimately, to the absence of an increase in its own revenues (Figure 12).

Calculation of tax potential can be based on the assessment of the tax base in the context of the corresponding type of cities by the aggregate indicator (similar to the gross domestic product, the volume of industrial production and turnover) or using the tax base by type of taxes (Dabla-Norris and Wade, 2002).

In case of using an aggregate indicator reflecting the overall level of development of the city's economy (i.e., tax potential), the assessment is based on the ratio of value-added (industrial production, wage fund) with the projected tax revenues from the unit of value-added (industrial production, wage fun) (Alfirman, 2003). If necessary, conversion factors for the sector structure of the city's economy can be used; they reflect differences in the level of entrusted tax revenues from the equal

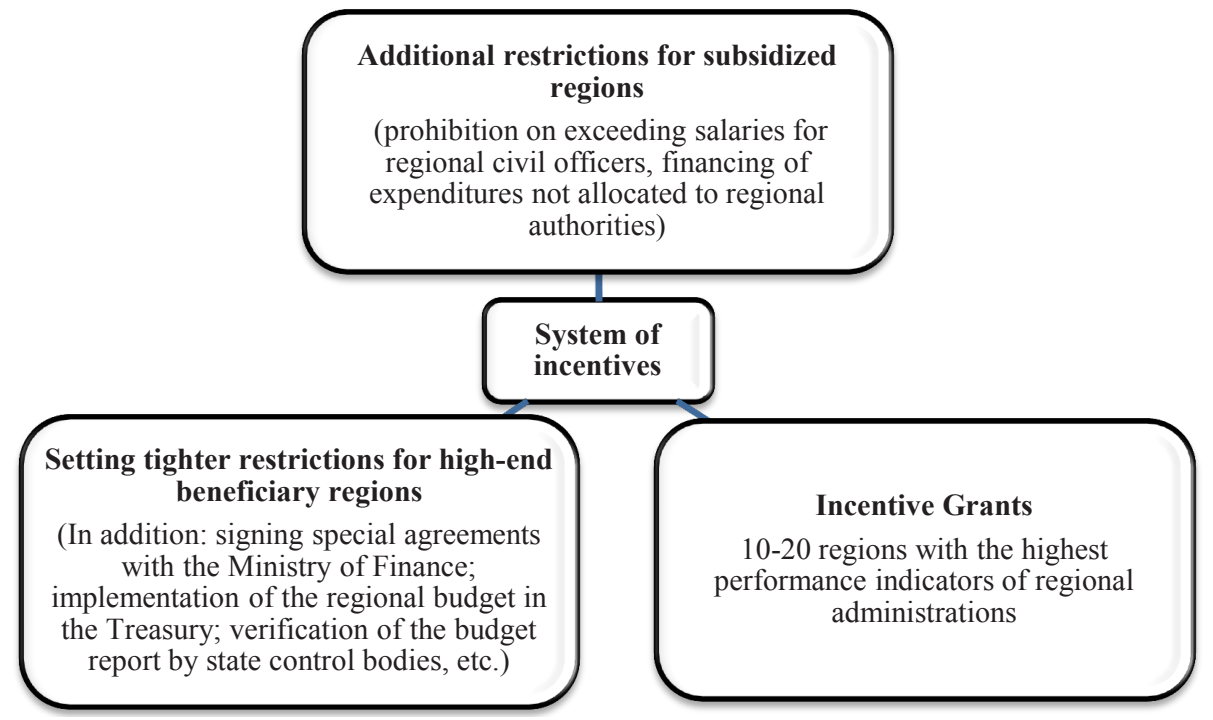

Figure 12. System of incentives for regional authorities

Source: The scheme was created by the authors based on (Dabla-Norris and Wade, 2002) 
amount of value-added (industrial production, wage fund) in various sectors of the economy of the city. It should be emphasized that the use of conversion factors is necessary in the case indirect taxes (for example, excise taxes on alcohol), as well as unevenly distributed resource payments (related to used aggregate indicators that are not directly correlated with value-added, industrial production, wage fund) are transferred to cities.

The formula for calculating the tax potential (TCU $\ll \mathrm{X} »$ ) (Alfirman, 2003) in the case of Ukraine is the following:

$$
T C U \ll X »=F T R * V D U \ll X » * C F U \ll X » / T V A U
$$

The tax capacity of the " $X$ " city of Ukraine = total Ukrainian forecast for tax revenues in cities of this type * the amount of value-added (industrial production, wage fund) in the city " $\mathrm{X}$ " of Ukraine * conversion factor for the sector structure of the " $\mathrm{X}$ " city's economy of Ukraine / total value added in Ukraine (industrial production, wage fund).

The conversion factor for the sector structure of the city's economy $(C F U$ « $X$ ») is determined by the formula (Holtz-Eakin and Rosen, 1988; De Borger, 1994):

$$
\begin{aligned}
& C F U \ll X »=\sum\{(A V A U \ll X Y » / A V A U \ll X ») \times(R \ll Y » / R) / \\
& /(A V A U \ll Y » / A V A U)\}
\end{aligned}
$$

Conversion factor $=\Sigma$ (amount of value-added (industrial production, wage fund) in " $Y$ " branch of the economy (industry) in the " $\mathrm{X}$ " city of Ukraine) / (value-added (industrial production, wage fund) in all branches of economy (industry) in the "X" city of Ukraine) * (projected (reporting) volume of all tax revenues assigned to cities, for " $Y$ " sector of the economy (industry) of Ukraine) / (forecast (reporting) volume of all tax revenues assigned to cities in all sectors of the economy (industry)) of Ukraine / (value-added (industrial production, wage fund) in the "Y" sector of the economy (industry) in all cities of Ukraine) / (value-added (industrial production, wage fund) in all sectors of the economy (industry) in all cities of Ukraine).

At the same time, in order to ensure the most stable distribution of financial assistance, it is necessary to use the reporting data for several periods (years) to determine the tax potential.

Tax potential can also be estimated by types of taxes in the case of the possibility to allocate and estimate indirect metrics of the tax base of cities. For example, for land tax, the cadastral value of land could be used as an indicator (probably, with adjustments to certain defined benefits for certain categories of taxpayers); for taxes on small businesses - the volume of their turnover could be used (Brueckner and Saavedra, 2001).
The tax potential by type of tax should be assessed based on the assumption that the tax base available in the city is used with the region's average efficiency (the same amount of tax is levied from one unit of measurement in which the tax base is expressed). For these taxes, the tax potential is estimated by multiplying the indicator selected as the tax base for the average representative $^{3}$ tax rate. Thus, the average representative tax rate (for entities) is calculated as the ratio between the projected tax collections and the tax base of this tax for all cities (Brueckner and Saavedra, 2001).

$$
T C U \ll X Y »=T B U \ll X Y » \times T F T R U \ll Y » / T T B U \ll Y »(3)
$$

The tax potential of the city " $X$ " of Ukraine and from the "Y" tax of Ukraine ( $T C U$ « $X Y$ ») = the "Y" tax base of Ukraine in the " $\mathrm{X}$ " city of Ukraine in the forecast year * the total forecast of tax revenue "Y" of Ukraine to the budgets of all cities of this type of Ukraine / total tax base of the tax "Y" of Ukraine.

Thus, the tax potential for all types of taxes $(T C U$ « $X$ » ) for this calculation will be determined by the formula (Brueckner and Saavedra, 2001):

$$
T C U \ll X »=\sum(T C U) \ll X Y »(4)
$$

The amount of tax potentials in the city by type of taxes in the city " $X$ " of Ukraine (the amount of tax potential $)=\Sigma(\operatorname{tax}$ base of $\operatorname{tax}$ " $Y$ " of Ukraine in the city " $\mathrm{X}$ " of Ukraine in the forecast year).

When using the assessment of tax potential based on aggregate factors, it is not necessary to use separate accounting for a significant number of branches of economy and industry, especially if one takes into account the fact that the levels of tax burden practically do not differ for each of them. In the same way as the representative tax rates method is applied, which does not necessarily include the assessment of each type of tax (especially if its share in the city's tax revenues is insignificant).

The adjustment factor for expenditure should be used to assess the differences between cities of the same type to find the cost of providing one and the same amount of budget services per inhabitant in the area (DablaNorris and Wade, 2002; Gershberg and Winkler, 2004).

The use of an adjustment factor is necessary for the distribution of intergovernmental transfers for the cities with significant objective socio-demographic, climatic, geographical, transport and other conditions that determine the more or less high cost of an identical set of goods and services. In case that these differences are insignificant, the application of this coefficient is ineffective (Dabla-Norris and Wade, 2002; Gershberg and Winkler, 2004).

In general, the factor should represent the amount of budgetary funds to be used in the city for implementation

\footnotetext{
${ }^{3}$ Representativeness is the ability of the sample aggregate to reproduce the main characteristics of the general aggregate. Representativeness is achieved through the correct formation of a sample which must reproduce the overall object by principal for the study parameters.

Parameters like reliability and validity play a significant role in determining the quality of information obtained as a result of empirical research, in addition to representativeness.
} 
of its assigned budget service responsibilities, taking into account price factors, compared to the per capita average for all cities of the type considered, located within the respective territory (Dabla-Norris and Wade, 2002; Gershberg and Winkler, 2004).

The Financial Support Fund distribution based on the assessment of the level of budget security must be carried out in order to increase this level in the least secured cities.

The level of budget security shows how many times more or less the amount of budget revenues of a particular city is (reduced to a comparable type by accounting for price factors and the number of consumers of budget services), the average per capita income of all cities of this type (Dabla-Norris and Wade, 2002; Gershberg and Winkler, 2004). The level of budget provision of cities by their own revenues to the distribution of funds of financial support funds $(B P U \ll X »)$ may be determined by the following formula (Gershberg and Winkler, 2004; Brueckner and Saavedra, 2001):

$$
\begin{aligned}
& B P U \ll X »=(T C U \ll X » /\{P U \ll X » \times A F E N U \ll X »\}) / \\
& /(T F T R U / P U)
\end{aligned}
$$

The level of budget provision of the city " $\mathrm{X}$ " of Ukraine to the distribution of the Financial Support Fund finances $=$ the tax potential of the city " $\mathrm{X}$ " of Ukraine / population of the city " $X$ " of Ukraine * adjustment factor of the city's expenditure needs " $\mathrm{X}$ " of Ukraine / total Ukrainian forecast for tax revenues in cities of one type / population of the city, oblast of Ukraine.

If the level of budget provision of the city, obtained using this formula, is more than one, then it is provided with income more than all cities of this type (by 20\%). And if the level of budget security is less than one, then this city's income is less than average among cities of this type (60\% of the average level) (Dabla-Norris and Wade, 2002; Gershberg and Winkler, 2004). The next step after determining the levels of budget provision of cities of the same type is ranking by levels.

In general, the main purpose of allocating financial support for cities is to reduce the differences (equalization) of the level of local budget revenues (compared considering population and price factors) by increasing the amount of financial resources in the least secured tax revenue cities, in order to ensure the highest possible budget services to the population (in accordance with the powers of local self-government bodies).

Equalization of budget security is carried out by various methods, in particular, by the method of proportional equalization, alignment to the maximum possible level, and the combined method.

Thus, the proposed model of principles, tools and mechanism of distribution and regulation of intergovernmental fiscal flows will provide an opportunity to ensure the unity of all levels of the budget system and their interaction, which, in turn, will ensure macro-financial stability of the state, efficient allocation of budget expenditure, development of society's democratization and uniform socio-economic development of regions of Ukraine.

\section{Conclusion}

The issue of intergovernmental regulation of cash flows is of great current interest due to the following challenges: the policy of European integration; carrying out the decentralization of power reform; increasing population migration; devaluation of the national currency; military-political tension; negative dynamics of macroeconomic indicators; economic turbulence; reduction of investment attractiveness; outflow of skilled labour; and reduction of expenditures for the following socially significant areas: health care, education, social assistance for the elderly. The proposed model of principles, tools and mechanism of distribution and regulation of intergovernmental fiscal flows will provide an opportunity to ensure the unity of all levels of the budget system and their interaction, which, in turn, will ensure macro-financial stability of the state, efficient allocation of budget expenditure, development of society's democratization and uniform socio-economic development of regions of Ukraine.

\section{References:}

Alfirman, L. (2003). Estimating Stochastic Frontier Tax Potential: Can Indonesian Local Governments Increase Tax Revenues Under Decentralization. Center for Economic Analysis, University of Colorado at Boulder. Working paper. Working paper, 03-19.

Amenta, E. (2016). Neoliberal globalization, democratization, and movement responses. Mobilization: An International Quarterly, 21(4), 389-391.

Bordignon, M. (2006). Fiscal Decentralization: how to Harden the Budget Constraint. Fiscal Policy Surveillance in Europe, 109-136.

Brueckner, J. K., \& Saavedra, L.A. (2001). Do Local Governments Engage in Strategic Property - Tax Competition? National Tax Journal, 203-229.

Budget Code of Ukraine (2017). Law, № 2456-VI.

Cheng, J. (2018). Intergovernmental Relations, and Market Development. Springer.

Dabla-Norris, E., \& Wade, P. (2002). The Challenge of Fiscal Decentralization in Transition Countries.

De Borger, B. et al. (1994). Explaining Differences in Productive Efficiency: an Application to Belgian Municipalities. Public Choice, 80(3), 339-358. 
De Mello, L. et al. (2018). The Global Crisis and Intergovernmental Relations: Revisiting the Centralisationdecentralisation Debate ten years on presentation at the Third International Conference on "Decentralisation after the Great Recession: Fine-Tuning or Paradigm Shift.

De Mello, L. R. (2000). Fiscal Decentralization and Intergovernmental Fiscal Relations: a Cross-country Analysis. World Development, 28(2), 365-380.

Rodden, J., \& Eskeland, G. S. (2003). Decentralization F. the Challenge of Hard Budget Constraints.

Eccleston, R., \& Krever, R. (2017). The Future of Federalism: Intergovernmental Financial Relations in an Age of Austerity. Edward Elgar Publishing.

Fisman, R., \& Gatti, R. (2002). Decentralization and Corruption: Evidence from US Federal Transfer Programs. Public Choice, 113(1), 25-35.

Gershberg, A., \& Winkler, D. (2004). Education Decentralization in Africa: A Review of Recent Policy and Practice. Building State Capacity in Africa, 323.

State Statistics Service of Ukraine (2018).

Harvey, D. (2010). Social Justice and the City. University of Georgia Press, 1.

Holtz-Eakin, D., \& Rosen, H. S. (1988). Tax Deductibility and Municipal Budget Structure. Fiscal Federalism: Quantitative Studies. University of Chicago Press, 107-136.

IMF Data (2017).

Kyrylenko, O. P. (2001). Financial Independence of Local Self-Government. Finance of Ukraine, 1, 34-39.

Kyrylenko, O. P. (2002). Local Budgets in the Economic System of the State. Thesis for the Degree of Candidate of Economic Sciences: speciality 08.04.01 "Finance, Money Circulation and Credit".

Kyrylenko, O. P. (2004). Public Finances in the Conditions of Formation of a Democratic Society. The World of Finance, 1(1), 22-33.

Lunina, I. (2014). Budget Decentralization: the Goals and Directions of Reforms. Ekonomika Ukrainy (Economics of Ukraine), 11(636), 61-75.

Lyuty, I. O. (2004). Recent Trends in the Development of the Financial System of the State. Finance of Ukraine, 5, 24-29.

Lyuty, I. O. (2009). Theoretical and Methodological Principles of the Budget Policy of the State. Finance of Ukraine, $12,13-19$.

Marlow, M. L. (1988). Fiscal Decentralization and Government Size. Public Choice, 56(3), 259-269.

Nogin, V. D. (2005). Generalized Edgeworth-Pareto Principle and its Applicability Limits. Economics and Mathematical Methods, 41(3), 128-134.

Patsias, C., \& Latendresse, A., (2013). Participatory Democracy, Decentralization and Local Governance: The Montreal Participatory Budget in the Light of 'Empowered Participatory Governance. International Journal of Urban and Regional Research, 37(6), 2214-2230.

Prud'Homme, R. (1995). The Dangers of Decentralization. The World Bank Research Observer, 10(2), 201-220.

Rodden, J. (2000). Decentralization and the Challenge of Hard Budget Constraints.

Rodden, J., \& Eskeland, G. S. (2003). Fiscal Decentralization and the Challenge of Hard Budget Constraints. MIT press.

Saburov, N., \& Tipenko, N. (2001). Budget Federalism and Interbudgetary Relations. Problems of Economic Transition, 43(11), 76-92.

Stenberg, C. W., \& Hamilton, D. K. and Hamilton. (2018). Intergovernmental Relations in Transition: Reflections and Directions. Routledge.

Sutcliffe, J. B. (2017). Intergovernmental Relations in the European Union and Canada: The place of local government. Crossing the Atlantic. Routledge, 85-105.

Worldbank enforcement (2017).

Wright, D. S., \& Stenberg, C. W. (2018). Federalism, Intergovernmental Relations, and Intergovernmental Management: The Origins, Emergence, and Maturity of Three Concepts across Two Centuries of Organizing Power by Area and by Function. Handbook of public administration. Routledge, 407-479.

Grossi, G., \& Cinquini, L. (2018). External Pressures and Internal Dynamics in the Institutionalization of Performance-Based Budgeting: An Endless Process? Public Performance \& Management Review, 41(2), 224-252.

Grossi, G., \& Brorstrom, S., et al. (2018). Translating Sustainable and Smart City Strategies into Performance Measurement Systems. Public Money \& Management, 38(3), 193-202.

Grossi, G., \& Bourmistrov, A., et al. (2018). Participatory Budgeting as a Form of Dialogic Accounting in Russia: Actors' Institutional Work and Reflexivity Trap. Accounting Auditing \& Accountability Journal, 31(4), 1098-1123. 